\title{
ASSESSMENT OF WILDLIFE PESTS ON FADAMA FARMS ALONG RIVER BENUE (FROM ABINSI TO AGBOUGHUL SETTLEMENTS) IN MAKURDI LOCAL GOVERNMENT AREA OF BENUE STATE, NIGERIA
}

\author{
Uloko, I.J ${ }^{1}$ and Gwabo, B.T ${ }^{2}$ \\ Federal University of Agriculture, Makurdi, Benue State, Nigeria \\ http://doi.org/10.35410/IJAEB.2019.4455
}

\begin{abstract}
This study explored the effect of wildlife pests on the large expanse of fadama land from Abinsi to Agboughul Settlements in Makurdi Local Government Area of Benue State, Nigeria. Structural questionnaire such as focus group discussion (FGD) targeting young energetic farmers between the ages of 21-30 years was used. Random sampling technique was employed to select one hundred respondents from the two settlements, (50 each from the two settlements). The data obtained were subjected to descriptive statistics (such as frequency, percentages and tables). The result showed that cane rat (Thryonomys swinderianus) (37\%) and rabbit (Capensis cuniculus) (32\%) caused the most damage to the Fadama crops as compared to giant snails, (Achatina achatina (11\%) and Nile rat (Arvicanthis niloticus) (20\%). Furthermore, $44 \%$ of the farmers agreed that the animals visited the farms at night and while $25 \%$ and $11 \%$ believed the visits were in both night and early morning respectively. Attempt to control the wildlife pests revealed that most species continually killed could be as a result of lack of awareness campaign, agro forestry practices and integrated farming system. These endangered species or at least threatened may pose a dangerous trend to our wildlife conservation principles. However, this can be minimized through well planned education programmes for the farmers.
\end{abstract}

Keywords: Fadama, Wildlife, Pest, floodplain, Season.

\section{INTRODUCTION}

Fadama farming is practiced along major floodable plains and Savannah Rivers mainly to increase the farmers' self sufficiency in food production and income. Increase in food production is achievable through increased agricultural activities in both wet and dry seasons, (Junk et al, 1989). The National Fadama development was structured into developmental stages for efficiency in implementation strategy, (Obieching, 2000). The project design is both participatory and socially in nature.

The approach is to empower farmers to take control of/ and manage their resources for their own development, (Aderinola, 2001). The programme is expected to reduce the poverty level of small holder farmers through increased agricultural production and the attendant income, (Ogunlela, 2008). The major financiers are the World Bank (WB), African Development Bank (ADB) and Nigerian Government, (NFDO, 2005). Fadama farmers in Benue State, Nigeria utilize the large expanse of Fadama lands in these areas for both crop production and grazing. Other activities 
include fishing/fish farming and a forestation programmes, (NFDO, 2007).

However, there are numerous challenges militating against the optimum derivable benefits that the Fadama has to provide to stakeholders. The most important of these challenges is that of Wildlife pests raids, apart from insects, diseases and weed management in crop lands. Intensification of agricultural activities has often brought with it pest related problems.

For example, harmful chemicals threaten the environment and human health alike (Cooper and Dobsona, 2007).

Therefore, integrated pest management (IPM) has emerged as a way towards maintaining or increasing agricultural productivity without over- reliance on synthetic chemical pesticides. One of the fundamental principles of IPM emphasizes the need not only to deal with pests and diseases once they have become a problem but also to promote the growth of healthy crops or livestock in trying to conserving the natural resources base, (Nathaniels et al, 2003). However, well detailed informations about farmers' awareness of wildlife pests and diseases are necessary in fashioning programmes that would aid the realization of the objectives of the Fadama programmes.

\section{MATERIALS AND METHODS}

Study Area: This study was carried out and concluded on Fadama farms along the River Benue in Abinsi and Agboughul settlements in Makurdi Local Government Area of Benue State, Nigeria between March 2014 and April 2015. Makurdi (study Areas) lies between latitude $7^{0} \cdot 44^{1}$ to $8^{0} .22^{0} \mathrm{~N}$ and longitude $8^{0} .32^{1} \mathrm{E}$ and $8^{0} .44^{1} \mathrm{E}$ with an altitude of $112 \mathrm{~m}$ above sea-level.

Vegetation and Climate:

This area lies within Guinea Savannah vegetation, characterized by two clear distinct wet and dry seasons. Rainy seasons begins from April to October, averaging $1524 \mathrm{~mm} / \mathrm{annum}$ and temperature ranging between $28^{\circ} \mathrm{C}-30^{\circ} \mathrm{C}$ most times of the year. Dry season begins from November to early April with dry harmattan wind and temperature ranging from $20^{\circ} \mathrm{C}$ to $35^{\circ} \mathrm{C}$.

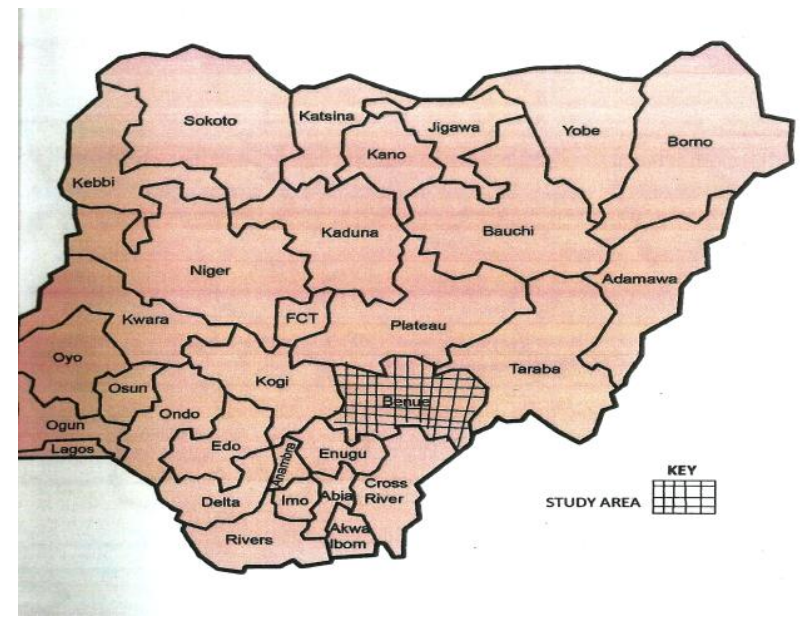


Fig1\&2: Maps of Nigeria/Benue state/study Area(Abinsi to Agboughoul settlements.

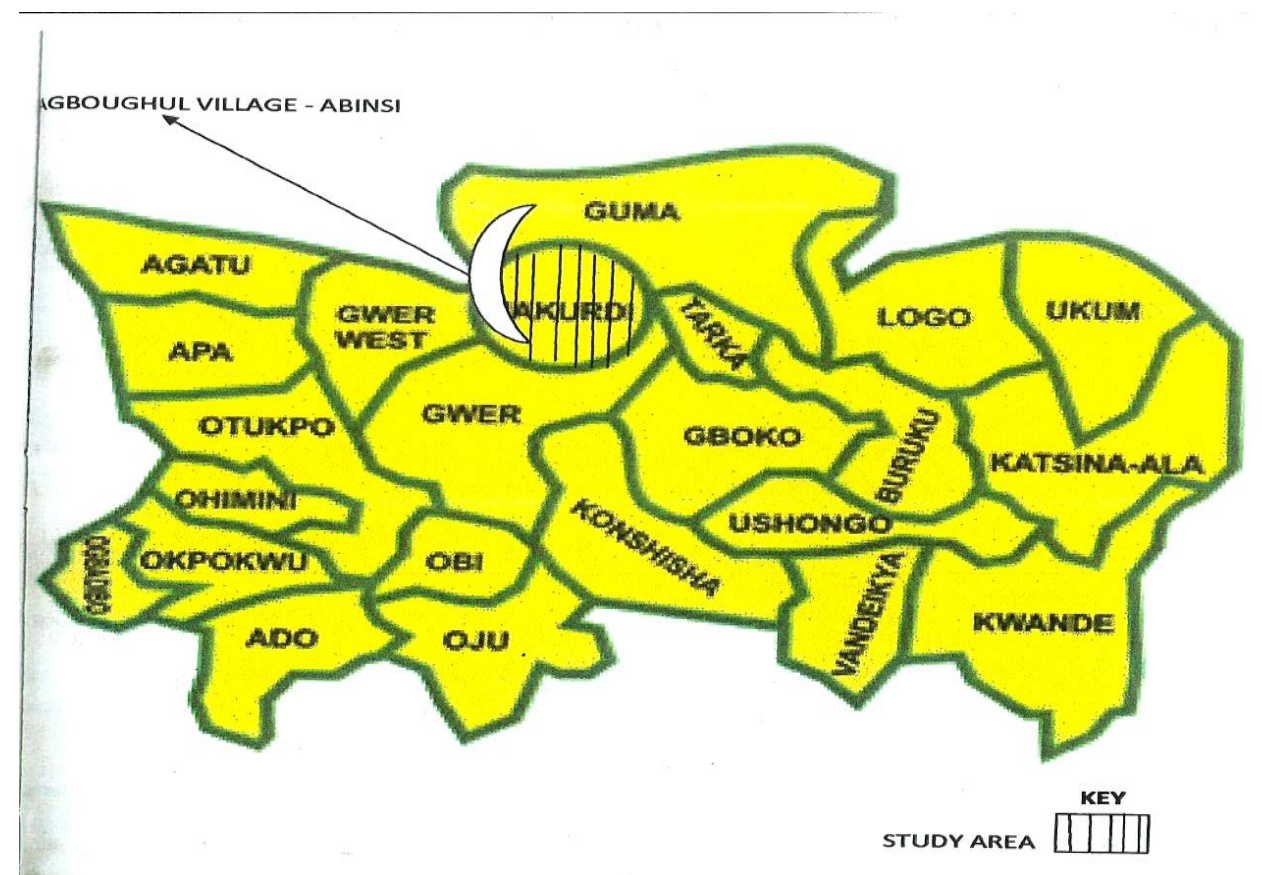

\section{Farming Activities/Far}

\section{Farmers Activities/Farm Products:}

The farmers were predominantly Hausa, Tiv, Kabawa and Jukum people living along the bank of the River Benue (Abinsi and Agboughul areas). The agricultural products include the followings: cassava, Guinea corn, rice, sugar cane, vegetable, garden eggs, green leafy vegetables (Ugwu leaf), groundnut, potatoes, tobacco and maize. During dry season, irrigation is predominantly practiced. Wild animals species found in the area as pests include giant rat (Cricetomys gambianus); cane rat (Thryonomys swinderianus); Squirrel (Xerus erythropus); Nile rat (Arvicanthus nilotecus), weaver birds (Ploceus cucullatus cuculatus) and reptiles such as giant tortoise (Kinxys crosa).

\section{Farm Size:}

Most of the farm size in both study areas were between 1-2 hectares per farmer along the bank of River Benue.

Farmers Age Group:

From the data collection, the farmers age were between 18-20 years (school age); young farming age (between 21-30 years) and strong elderly between the age of( $41-51$ years).

Methodology:

Structural Questionnaire (Focus Group Discussion) was designed for the farmers. One hundred 
questionnaires were administered on one hundred respondents (50 each from Abinsi and Agboughul). Frequent visits (three times per week) were also made to farms where wildlife pests could be sighted physically with the kind of damage to crops and parts of crop affected during the farming/harvesting seasons. Subsequently, animal burrows, feeding sites and affected crop types were examined. The information collected from the farmers include, wildlife species causing damage, the time of visit of the animal to the farm, parts of the crops/plants damaged, the period of the year these animals caused most damaged, the level of damage, the residence of the animal and methods of control. These informations were then tabulated and percentage frequency obtained.

Data collection

Primary data were obtained from structural questionnaire (Focus Group Discussion) administered to 100 farming Respondents from the two villages (i.e. 50 each from Abinsi and Agboughul). Secondary data were also obtained from oral interviews and unpublished materials. Data Analysis

The data were analyzed using descriptive statistic such as frequency, percentages and tables.

\section{RESULTS}

Table 1: Wildlife pests that caused damage to crops at Agboughul and Abinsi

\begin{tabular}{|c|c|c|c|c|}
\hline $\mathrm{S} / \mathrm{N}$ & Common Names & Scientific Name & Agboughul & Abinsi \\
\hline 1. & Rabbit & & + & - \\
\hline 2. & Cane rat & & + & + \\
\hline 3. & Giant tortoise & & - & + \\
\hline 4. & Nile rat & & + & + \\
\hline 5. & Squirrel & & + & + \\
\hline 6. & Giant rat & & + & + \\
\hline 7. & Grasshopper & & + & + \\
\hline 8. & Cricket & & + & + \\
\hline 9. & Termites & & + & + \\
\hline 10. & Birds & & + & + \\
\hline
\end{tabular}

Source: Field Survey (2014/2015)

$(+)=$ Present

$(-)=$ Absent

Most wildlife pests were found in both study areas except that Giant tortoise was not seen in Agboughul while rabbit was absent at Abinsi farms.

Table 2: Different crops and pest infestation in Agboughul + Abinsi

\begin{tabular}{|c|c|c|}
\hline \multirow[t]{2}{*}{$\mathrm{S} / \mathrm{NO}$} & Name of Crop & Specific types of wildlife pest infestation \\
\hline & Common Name & Scientific Name \\
\hline 1. & Sugar cane & Cane rat \\
\hline 2. & Rice & Birds/Grasshopper \\
\hline 3. & Maize & Birds/Squirrel \\
\hline
\end{tabular}


International Journal of Agriculture, Environment and Bioresearch

Vol. 4, No. 06; 2019

ISSN: $2456-8643$

\begin{tabular}{|lll|}
\hline 4. & Cassava & Nile rat \\
5. & Vegetables & Cricket \\
6. & Potatoes & Termites/Cane rat \\
7. & Tobacco & Bug \\
8. & Groundnut & Squirrel/Rat \\
9. & Guinea corn & Birds/rat \\
10. & Yam tuber & Nile rat \\
\hline
\end{tabular}

Source: Field Survey $(2014 / 2015)$

Table 2 showed the specific types of wildlife pest infestation in both Abinsi and Agboughul settlement in Makurdi Local Government Area of Benue State, Nigeria.

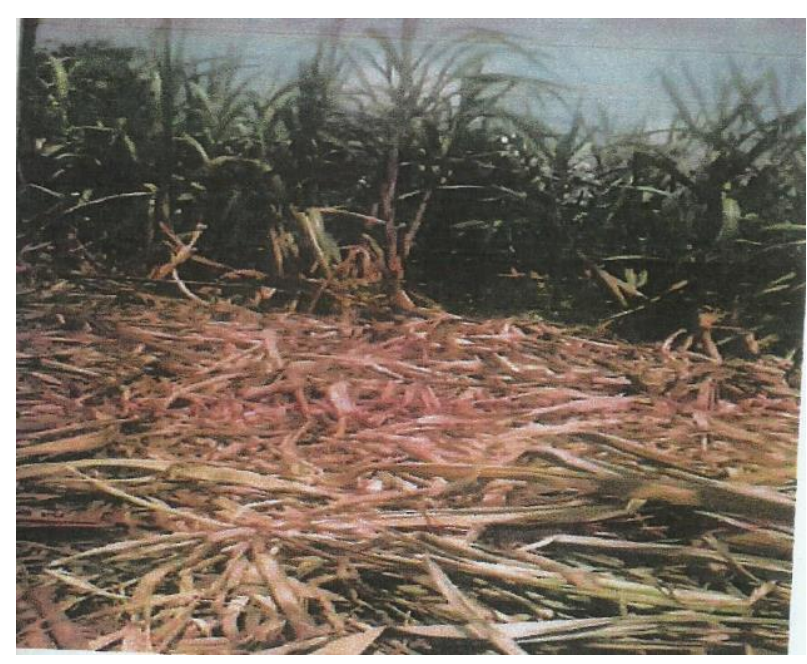

Plate 1: Stalks of sugar damaged by wild animal pests

Sources: field survey (2014). 


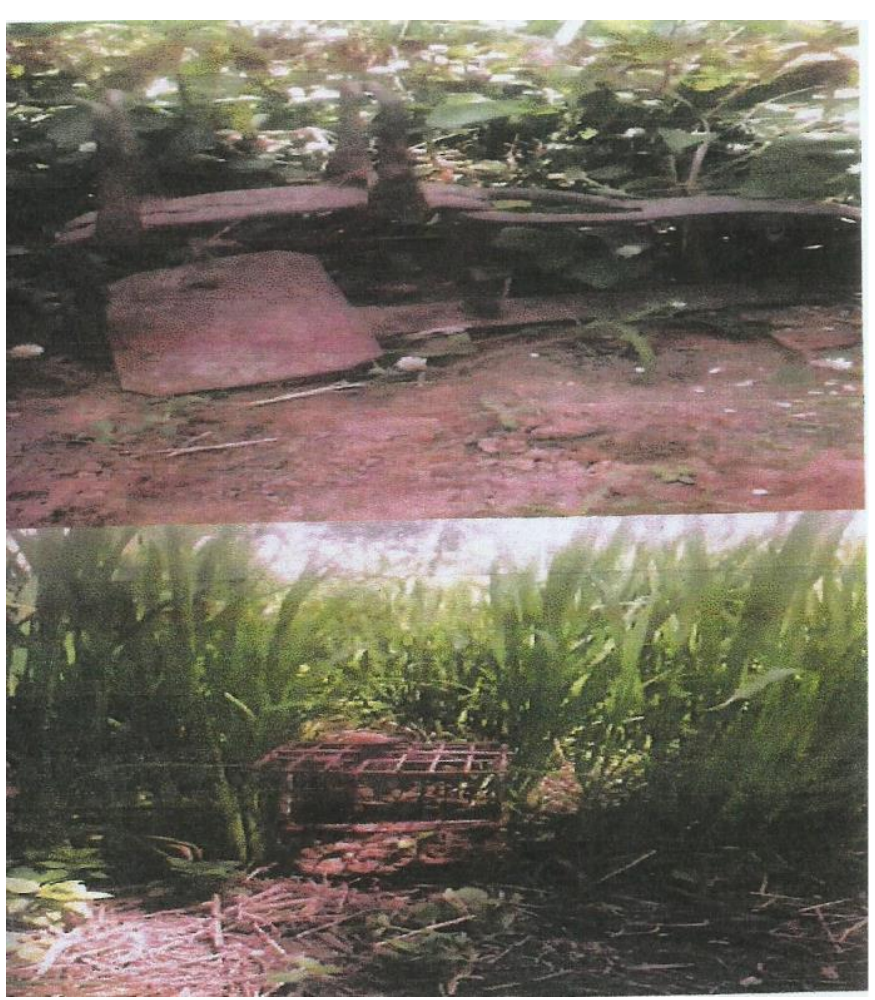

Plate 2: Tools used in killing wild animal pests

Sources: Field survey (2014).

Table 3: Demographic/social-economic status of the respondent

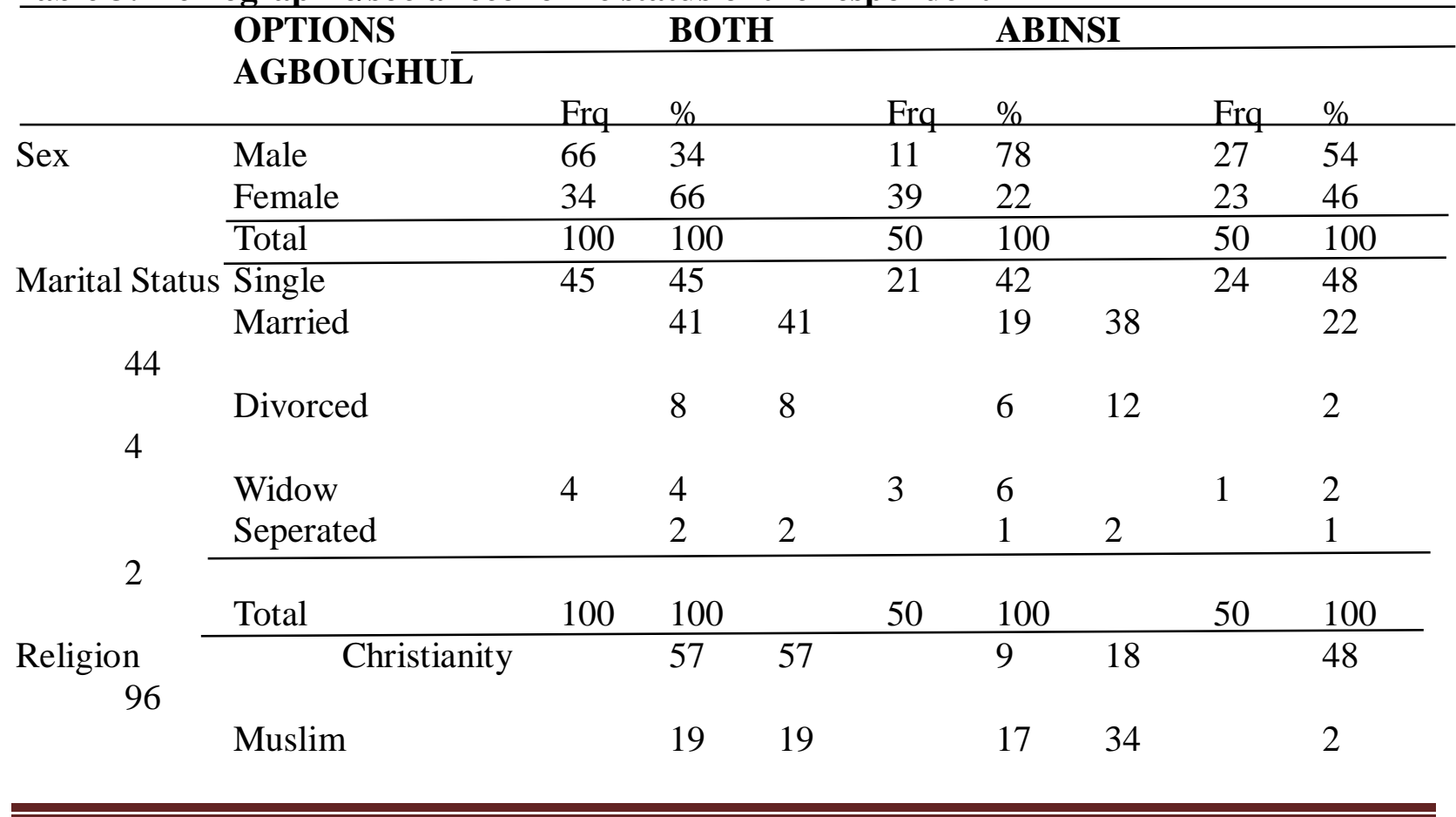


Vol. 4, No. 06; 2019

ISSN: $2456-8643$

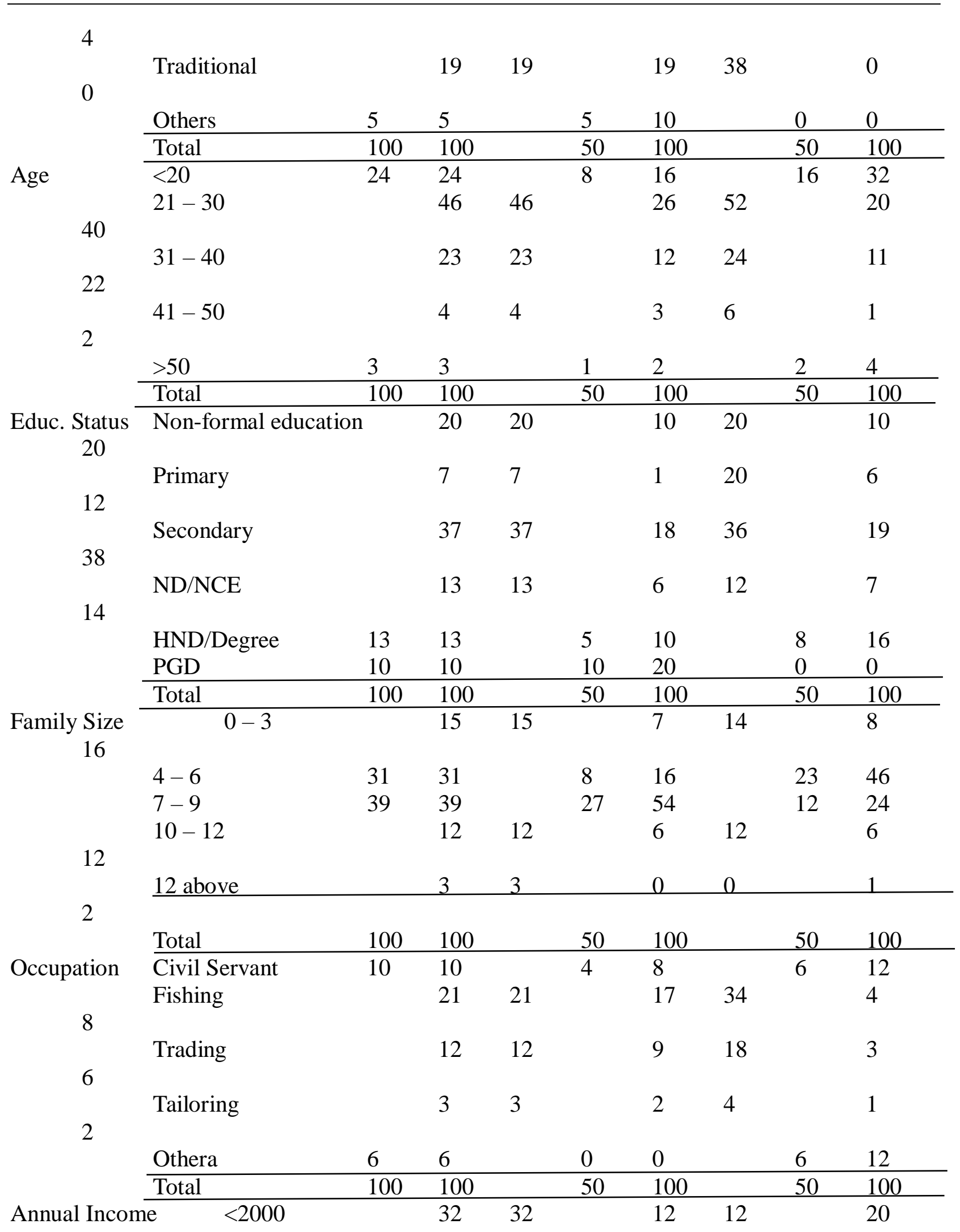




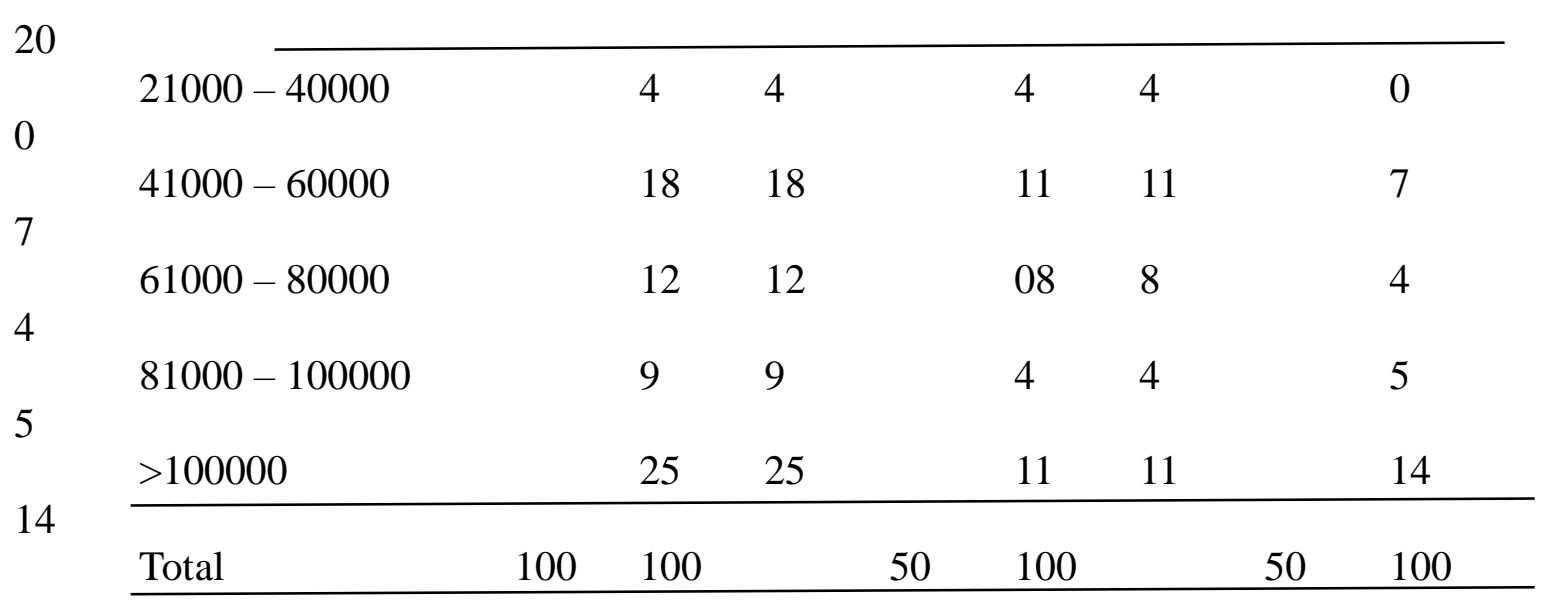

Source: Field survey, ( 2014)

From table 3, 66\% of the respondents were males while $34 \%$ were females. Furthermore, $45 \%$ were single, $(41 \%)$ married, $8 \%$ divorced, $(4 \%)$ widows and (2\%) separated. Also, $(57 \%)$ were Christians, (19\%) Muslims and traditional worshippers others, (5\%). However, $46 \%$ of the farming population were between 21-40 years of age, while 24\% were less than 21 years of age which were the most active age for farming. Educationally, $37 \%$ had secondary school education, $13 \%$ were ND/NCE holders while $20 \%$ had no formal education and only $7 \%$ attended primary school. Also, 39\% of the farmers had household size of 7 to two persons; 31\% had 4-6 persons while $30 \%$ had household size between 0-4 persons. From the table also, the major occupation of the farmers was crop farming (48\%) while $21 \%$ went into fishing. Traders and Civil servant had $2 \%$ and $10 \%$ respectively. In income generation, $32 \%$ had an annual income less than \#20, 000 while $25 \%$ had an annual income of above \#100, 000.

Table 4: Activities of pests and level of Destruction

OPTIONS BOTH ABINSI

AGBOUGHUL

\section{Other works apart from farming}

5

30

40

14

30

\section{4}

Student

Trading

Tailoring

Others

\section{Civil Servant}

Frq

Frq $\% \quad$ Frq $\%$

$\begin{array}{llll}23 & 23 & 18 & 36\end{array}$

$\begin{array}{lllll}31 & 31 & 16 & 32 & 15\end{array}$

$\begin{array}{llllll}23 & 23 & 3 & 6 & 20\end{array}$

$\begin{array}{llllll}18 & 18 & 11 & 22 & 7\end{array}$

$\begin{array}{lllllll}\text { Others } & 5 & 5 & 2 & 4 & 3 & 6\end{array}$


International Journal of Agriculture, Environment and Bioresearch

Vol. 4, No. 06; 2019

ISSN: $2456-8643$

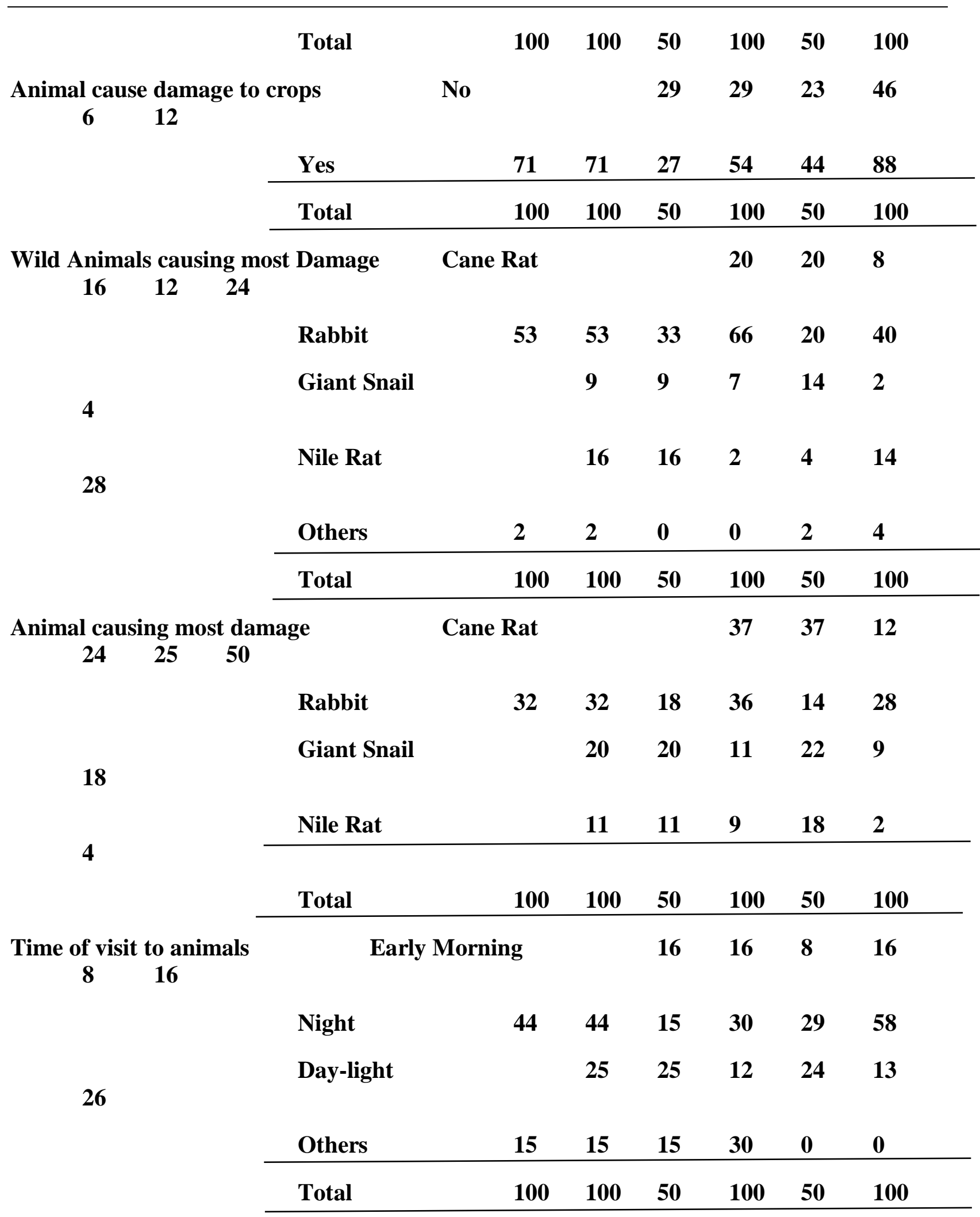


Part of crops damage

$16 \quad 32$

\begin{tabular}{|c|c|c|c|c|c|c|c|}
\hline & Stem & 39 & 39 & 23 & 46 & 19 & 38 \\
\hline & Seed & 32 & 32 & 13 & 26 & 11 & 22 \\
\hline & Bark & 24 & 24 & 13 & 26 & 4 & 8 \\
\hline & Others & 4 & 4 & $\mathbf{0}$ & $\mathbf{0}$ & $\mathbf{0}$ & $\mathbf{0}$ \\
\hline & Total & 100 & 100 & 50 & 100 & 50 & 100 \\
\hline Type of crop destroyed & Sugarcane & & & 32 & 32 & 17 & 34 \\
\hline & Rice & 31 & 31 & 28 & 56 & 15 & 30 \\
\hline 6 & Vegetable & & 3 & 3 & 3 & 6 & 3 \\
\hline & Maize & 10 & 10 & 2 & 4 & 11 & 22 \\
\hline & Cassava & & 11 & 11 & $\mathbf{0}$ & $\mathbf{0}$ & 13 \\
\hline & Others & 13 & 13 & $\mathbf{0}$ & $\mathbf{0}$ & $\mathbf{0}$ & $\mathbf{0}$ \\
\hline & Total & 100 & 100 & 50 & 100 & 50 & 100 \\
\hline $\begin{array}{l}\text { Period of the year damag } \\
\quad 38\end{array}$ & is most Rainy & & 39 & 39 & 22 & 44 & 19 \\
\hline & Dry & 24 & 24 & 11 & 22 & 13 & 26 \\
\hline & All yr & 37 & 37 & 17 & 34 & 18 & 36 \\
\hline & Total & 100 & 100 & 50 & 100 & 50 & 100 \\
\hline $\begin{array}{l}\text { Level of damage } \\
56\end{array}$ & Heavy & & 38 & 38 & 10 & 20 & 28 \\
\hline & $\begin{array}{l}\text { Light } \\
\text { Others }\end{array}$ & $\begin{array}{l}46 \\
16\end{array}$ & $\begin{array}{l}46 \\
16\end{array}$ & $\begin{array}{l}26 \\
14\end{array}$ & $\begin{array}{l}52 \\
28\end{array}$ & $\begin{array}{l}20 \\
2\end{array}$ & $\begin{array}{l}40 \\
4\end{array}$ \\
\hline & Total & 100 & 100 & 50 & 100 & 50 & 100 \\
\hline Animals most abundant & Cane Rat & & & 32 & 32 & 29 & 58 \\
\hline 40 & Nile Rat & & 29 & 29 & 9 & 18 & 20 \\
\hline 22 & Giant Snail & & 14 & 14 & 3 & 6 & 11 \\
\hline
\end{tabular}


Vol. 4, No. 06; 2019

ISSN: $2456-8643$

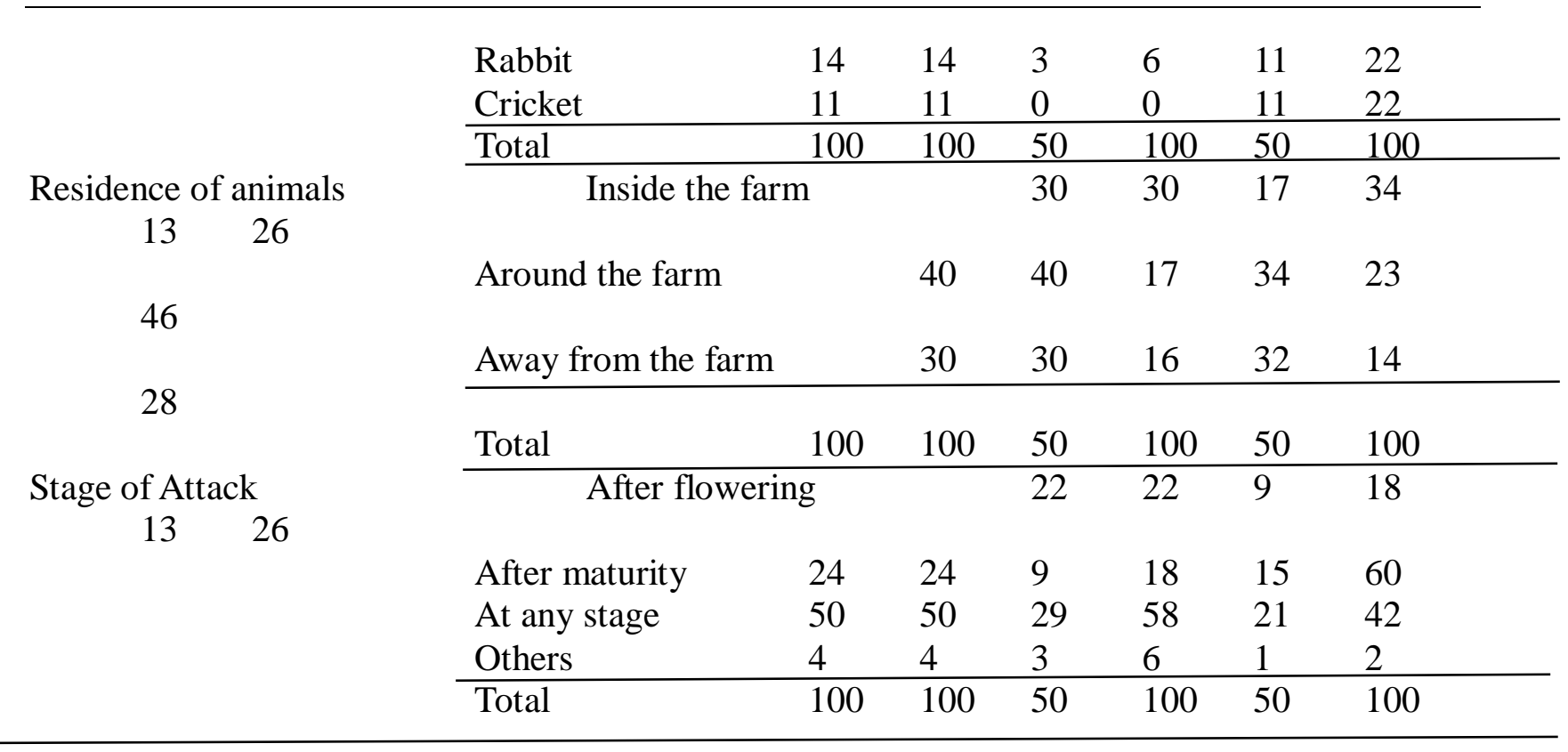

Source: Field Survey, 2014

From table 4, Cane rat (Thryonomys swinderianus) 20\% and Nile rat (Arvicanthis niloticus) $16 \%$ caused the most damage. While giant snail caused the least damaged. About $44 \%$ of the farmers agreed that animal visited the farms at night while $41 \%$ believed the visits were in the night and early morning.

However, $15 \%$ of the farmers were of the opinion that the wild animals visited the farms any time of the day. Also, from table 4, 39\% of the wild animal pest attacked stem while $32 \%$ destroyed the seeds; 24\% destroyed the bark and 5\% destroyed leaves and other parts. Most damage (39\%) was done during rainy season while $24 \%$ were mostly during dry season. However, $37 \%$ believed the damaged was all throughout the year. The result also revealed that $46 \%$ opined the damage was light while $38 \%$ indicated heavy damage. However, $16 \%$ could not really ascertain the level of the damage. From the table 4 also, the most abundant wildlife pests in the study areas was cane rat (32\%) while the least was cricket (11\%). The result also showed that $40 \%$ of the animals lived around the farm while $30 \%$ were believed to have lived inside and away from the farm respectively. Moreover, $50 \%$ of the farmers believed the attacked was at any stage while $24 \%$ and $22 \%$ concluded that the attacks were after matured and flowering plants respectively. 
Table 5: Control methods used for pests

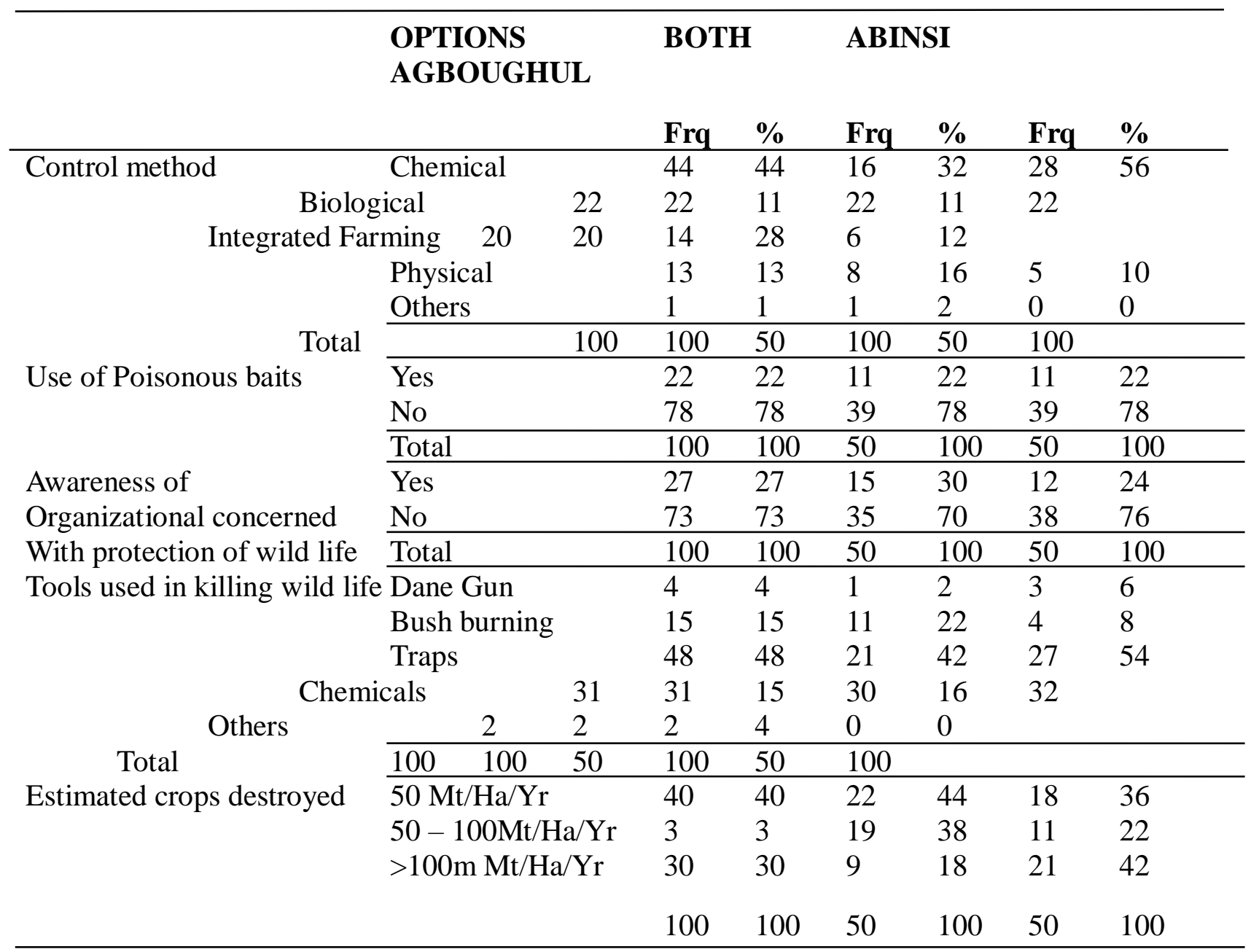

Source: Field Survey, (2014)

Table 5 showed the various method used by farmers in the study area to control pests. These were chemicals (44\%), biological method (20\%), while $20 \%$ uses integrated farming method, $13 \%$ and $1 \%$ uses physical and other method of controlling pests respectively.

In this table also, $22 \%$ of the farmers use poisonous bait to control pest while $78 \%$ do not used poisonous bait to control in the study area.

The result further showed that $27 \%$ of the FADAMA farmer were actually aware of the organization involved in the protection of wildlife pests protection.

Furthermore the farmers used traps (48\%), Chemical (31\%), and $15 \%$ used bush burning as a method in pest control. The result in the table showed the estimated crops destroyed $50 \mathrm{Mt} / \mathrm{Ha} / \mathrm{Yr}$ (40\%), while $30 \%$ believed it was far above $100 \mathrm{~m} \mathrm{Mt} / \mathrm{Ha} / \mathrm{Yr}$. 
Vol. 4, No. 06; 2019

ISSN: $2456-8643$

\section{DISCUSSION}

The effect of wildlife pests on FADAMA farms in Abinsi and Agboughul villages along River Benue in Makurdi Local Government Area was investigated. The survey was carried out during the dry season (November (2014)- April, 2015) during dry season farming activities in the Fadama areas. The quantity of crop/plants damaged was not accurately known since the farmers were not keeping the authentic records. However, the damage caused by the pests may represent a significant loss to the farmers who could only afford to cultivate small hectares (average of 1-2 hectares) of the farm land annually. Most of these wildlife pests are visible during dry burning period of late December to January. This was in line with the view of Ayodele and Akanbi (1993), during their work on effect of ecological study of wildlife pests on Fadama farms in Savannah zones of the middle belt of Nigeria.

From the 100 questionnaire administered on Fadama farmers and 20 farms visited showed that four major wildlife pests were identified with cane rats (Thryonomys swinderianus) as the most abundant representing $32 \%$ of the pest population. The abundance of cane rat may be due to high birth rate (litter size) as a reslut of abundance food in the study areas, (Odoh, 1993). However, the numbers of crops and plant damaged in Agboughul Fadama farms were less than that of Abinsi. This might be as a result of the proximity of Agboughul to Makurdi main town being a sub-urban community with major cosmopolitan disturbing influences from Makurdi town.

According to the Fadama farmers majority of the wildlife pests (44\%) were essentially nocturnal, apparently as an adaptation to avoid predators. But other species, notably the Nile rat, Arvicanthus niloticus were more active both day and night.

It was also revealed that the stem, seed and bark were the parts of crops/plants mostly damaged by the wildlife pests e.g. sugar cane, rice and cassava. About $40 \%$ of the respondent indicated the presence of these wildlife pests in the farms.

Probably, this is because suitable habitats such as shrub and grasslands, warehouses and domestic premises served as home and harbor these wildlife pests, (Funmilayo, 2008). The pest control measures adopted by farmers, though not very effective included traps $(48 \%)$, chemicals (31\%), bush burning (15\%), use of dane gun (4\%) and biological method such as the use of hunting dogs (22\%). It is wise to mention here too that these methods were inimical to wildlife conservation principles.

Usually, wildlife legislations forbid the capture of pregnant females, infant and nursing parent stock in order to enhance procreation and perpetuation of the stock species, (Palmer and Martin, 1999). Also, the poison baits used in hunting/killing these wildlife fauna pests, endangered the life of the final consumers of the 'bush meat' and the farm products, (Bamgbose et al, 1996).

\section{CONCLUSION}

This study indicates that wild animal pests caused damage to crops even on Fadama farms. This brings about economic loss to the Fadama farmers and therefore discourages them from large scale Fadama farming. Also, most of the captured/killed wildlife pests could be endangered or threatened thereby negating the value or essence of wildlife conservation principles. However, this fear can be minimized through well planned education and awareness campaign, Agro forestry practices and integrated farming system, (IFS).

\section{RECOMMENDATION}


1. Use of scare crow should be encouraged among local FADAMA farmers to scare particularly, the Avian species.

2. Farm patrol at regular intervals by both farmers and game patrol at team to study the movements of these animals should be encouraged into track them down.

3. Clearing of bushes in farm surrounding and inside the farms be carried out regularly to discourage the habitation of farms by these wildlife pests.

4. Introduction of wildlife extension services to educate farmers on wildlife conservation principles should be encouraged e.g. using integrated farming system.

\section{REFERENCES}

Adermola, E.A. (2001): Strategic planning and mission that most of the respondent are married, Literate and review for FADAMA projects in Ondo State, Nigeria.

Ayodele, I.A and Akanbi, O.A, (1993): The distribution of wildlife resources in relation to water holes and River Ogun in old Oyo National Park; $23^{\text {rd }}$ Annual Conference of FAN Nov. 29- Dec. 3, 1993; 200-208.

Bambose O.S et al, (1996): Influence of environmental degradation on the tissue concentration of copper, lead and Zinc in grasscutter (Thryonomys swinderianus) Temminck. Journal of tropical forest.

Cooper, J. and Dobson, H. (2007): The benefit of pesticides to mankind and the environment. Crop protection 26, 1337-1348.

Funmilayo, O; (2008): Vertebrate pests of rice in Southern Nigeria PANS 23 (1): 38-48.

Junk, E and Sparks, R.E, (1989): The flood pulse concept in River- flood plain systems.

Nathaniel et al; (2003): IPM for control of cashew powdery mildew in Tanzania.

National FADAMA Development Office (NFDO), 2005: Fadama development project poverty reduction and increased productivity through empowerment.

Obiechima, C.O.B, (2000): Increased food production and alleviating poverty through Fadama (Small scale irrigated farming in Anambra State.

Odoh, S.O, (1993): A survey of wildlife in bush meat market in Riviers and Abia States of Nigeria Forestry for urban Development. $23^{\text {rd }}$ Annual Conference of FAN Nov., 29- Dec 3 (1): 139- 144.

Ogunleda, V; (2008): Alleviating Rural Poverty in Nigeria.

Palmer, A and Martin, B; 1999: Faith in Conservation, Washington D.C. the World Bank. P.46 